\title{
Content of mineral- and sulphur compounds in Hungarian and French garlic varieties
}

\author{
Iváncsics, J., Gombkötő, Cs., Gombkötő N. \& Máthé, Á. \\ University of West Hungary, Faculty of Agriculture and Food Sciences, Institute of Plant Sciences. H-9241, \\ Mosonmagyaróvár
}

Summary: In our days about 2 million tons of garlic are grown in the world. Garlic was used as medicine already in ancient Egypt. It contains approx 33 sulfur compounds, several enzymes, 17 amino acids and minerals. We determined the content of diallyl sulfone, boron, calcium, copper, iron, potassium, magnesium, natrium, phosphorus and zinc in five garlic varieties (3 French, 2 Hungarian). We searched if there were signifficant differences between the varieties.

Key words: garlic, diallyl sulfone, microelements, minerals

\section{Introduction}

Garlic is a very considerable plant for the horticultural section, its average yield can reach the 10-15 t/ha. The largest quantity of this plant is grown in Asia, mainly in China. In Europe there are three important state of garlic growing: Spain, France and Italy (Table 1). Argentina, Egypt, Mexico, and California (USA) have also very important role in production.

On the biggest part of Hungary the proper environmental conditions are given for the realisation of the efficient garlic growing, however the growing is concentrated on a relatively narrow area: surround of Makó, and surround of Dusnok which can be found in Bács-Kiskun county. The Table 2 shows that the quantity of the produced garlic in Hungary has a considerable decreasing compared to the previous years. It was caused by the cheap imported garlic from the Chinese markets. In European Commission occurred the matter of discussion that the importation of the garlic should have to be made subject to licence from the third countries, this would be able to regulate the present quota system, could get the Hungarian garlic production into a forefront again, which is popular in abroad, and has a excellent quality (Gombkötö and Iváncsics, 2009a).

Garlic has been applied since time immemorial as a culinary spice and medicinal herb and is an important constituent of traditional Chinese medicine. The chief constituent of garlic is the sulfur compound allicin, produced by crushing or chewing fresh garlic, which in turn produces other sulfur compounds: ajoene, mono-, di-, and tri-allyl sulfides, and vinyldithiins (Koch and Lawson, 1996).

Garlic was used as medicine already in ancient Egypt. It emerges from a papyrus derived from 1550 before Christ, that this plant was used for heart-, head- and female diseases, and for bites.
However first a sumerian writing mentions garlic as medicinal plant, in 2100 before Christ. Hippocrates and Galenos point out the curative effects of this plant. In the ancient Greece and Rome it was used as a diuretic, or curing of respiratory tracts and didestive disorders. It was proposed for infectious diseases, toothache or epileptic attacks.

The phytopharmacines and phytotherapeutics are vegetal medicines, and garlic belongs to these too. This substances aren't used by grave diseaes of organs, but in the period, when the disease starts to evolve. Garlic can be named as geroprophylactic too. It means, that the formulation helps to prevent the ageing process before its time (Sillner, 1990).

Table 1. The harvested quantity of the garlic in the EU countries (1000t)

\begin{tabular}{|l|r|r|r|r|r|r|}
\hline & 1999 & 2000 & \multicolumn{1}{|c|}{2001} & 2002 & 2003 & 2004 \\
\hline Austria & 0.1 & 0.1 & 0.2 & 0.2 & 0.2 & 0.2 \\
\hline Bohemia & 7.7 & 7.1 & 5.4 & 2.2 & 1.0 & 0.6 \\
\hline Ésthonia & 0.1 & 0.1 & 0.1 & 0.1 & 0.1 & \\
\hline Finnland & 0.0 & 0.1 & 0.1 & 0.0 & 0.0 & \\
\hline France & 30.7 & 30.2 & 30.5 & 31.7 & 26.7 & \\
\hline Greece & 13.2 & 17.2 & 13.8 & 15.7 & 15.1 & 15.1 \\
\hline Latvia & 0.3 & 0.2 & 0.7 & 0.9 & 1.2 & \\
\hline Lithuania & & & & & 1.9 & 1.1 \\
\hline Hungary & 13.6 & 13.8 & 13.0 & 10.1 & 6.8 & \\
\hline Malta & 1.0 & 1.1 & 0.6 & 0.5 & 0.8 & 0.8 \\
\hline Italy & 30.5 & 31.6 & 34.5 & 28.1 & 25.3 & 26.5 \\
\hline Spain & 178.1 & 187.0 & 175.1 & 194.7 & 188.9 & 157.1 \\
\hline Slovakia & 5.3 & 4.3 & 0.3 & 0.3 & 0.3 & \\
\hline Slovenia & 0.8 & 0.5 & 0.3 & 0.3 & 0.3 & \\
\hline
\end{tabular}

Source: Eurostat 
Table 2. Data of garlic cultivated in Hungary onto all of the economies projected (Gombkötő and Iváncsics, 2009b)

\begin{tabular}{|l|c|c|c|c|c|c|c|c|}
\hline & $\begin{array}{c}\text { Aver- } \\
\text { age of } \\
1995- \\
2000\end{array}$ & 2001 & 2002 & 2003 & 2004 & 2005 & 2006 & 2007 \\
\hline $\begin{array}{l}\text { Harvested arable land } \\
\text { area of garlic (ha) }\end{array}$ & 1929 & 1657 & 1645 & 1259 & 889 & 1295 & 1122 & 641 \\
\hline $\begin{array}{l}\text { The total production of } \\
\text { garlic (ton) }\end{array}$ & 15981 & 13016 & 10065 & 6761 & 8360 & 9681 & 7291 & 5156 \\
\hline $\begin{array}{l}\text { Average yields of garlic } \\
\text { (kg/ha) }\end{array}$ & 6520 & 6140 & 4570 & 3380 & 6800 & 5770 & 5680 & 5320 \\
\hline
\end{tabular}

Source: KSH

Generally garlic bulb contains approximately $65 \%$ water, $28 \%$ carbohydrates (mainly fructans), 2,3\% organosulfur compounds, $2 \%$ protein (mainly alliin), $1,2 \%$ free amino acids (mainly arginine), and 1,5\% fiber (Blumenthal et al., 2000).

Garlic contains approx 33 sulfur compounds (aliin, allicin, ajoene, allylpropyl disulfide, diallyl trisulfide, sallylcysteine, vinyldithiines, S-allylmercaptocystein, and others) (Table 3), several enzymes (allinase, peroxidases, myrosinase, and others), 17 amino acids (arginine and others), and minerals (Selenium, germanium, tellurium and other trace minerals) (Omar and Al-Wabel, 2010).

Numerous clinical trials with garlic cloves and standardized garlic powder tablets leave little doubt that modest amounts of garlic have significant cardiovascular effects by reducing serum cholesterol, blood pressure, and platelet aggregation. Epidemiological and animal studies strongly indicate significant anticancer effects, particularly for the intestinal tract. Furthermore, its intestinal and topical antimicrobial activities have been its longest recognized effects. Identification of the compounds essential to the activity of garlic, mostly ascribed to its high content of sulfur compounds, has only been partially resolved (Lawson, 1998).

In recent years, extensive research has focused on the anticarcinogenic potential of allium vegetables and their constituents, allylsulfides and flavonoids (particularly quercetin which is present abundantly in onion). Epidemiological studies have shown that higher intake of allium products is associated with reduced risk of several types of cancers. Organosulfur compounds present in Allium vegetables, are considered to be responsible for the beneficial effects of these herbs. Several mechanisms have been proposed to explain the cancer - preventive effects of Allium vegetables and related organosulfur compounds. These include inhibition of mutagenesis, modulation

Source: Bianchini and Vainio, 2001 of enzyme activities, inhibition of DNA adduct formation, free-radical scavenging, and effects on cell proliferation and tumor growth. Associations between consumption of Allium vegetables and risk for cancer has been assessed in several epidemiologic, mainly case-control, studies. These have pointed to lower risks for cancers of the stomach, colon, esophagus, and perhaps breast. It is possible that diallyl disulfide and diallyl trisulfide is important in the anticancer action of garlic. More than one compound is responsible for the anticancer properties of garlic (Sengupta et al., 2004), (Omar and Al-Wabel, 2010).

Experimentally, garlic and its associated sulfur components are reported to supp-ress tumour incidence in breast, colon, skin, uterine, esophagus and lung cancers. A recent meta- analysis also showed that a high intake of garlic may be associated with decreased risks for stomach and colorectal cancer. Organosulfur compounds have been shown to modulate the activity of glutathione $S$-transferases

Table 3. Main organosulfur compounds present in Allium vegetables

\begin{tabular}{|c|c|c|}
\hline Chemical structure & Compound & $\begin{array}{l}\text { Abbrevia- } \\
\text { tion }\end{array}$ \\
\hline \multicolumn{3}{|l|}{ Lipid-soluble compounds } \\
\hline $\mathrm{CH} 2=\mathrm{CH}-\mathrm{CH} 2-\mathrm{S}(\mathrm{O})-\mathrm{CH} 2-\mathrm{CH}(\mathrm{NH} 2)-\mathrm{COOH}$ & S-Allylcysteine sulfoxide (Alliin) & \\
\hline $\mathrm{CH} 3-\mathrm{CH}=\mathrm{CH}-\mathrm{S}(\mathrm{O})-\mathrm{CH} 2-\mathrm{CH}(\mathrm{NH} 2)-\mathrm{COOH}$ & $\begin{array}{l}\text { S-Propenylcysteine sulfoxide } \\
\text { (lacrimatory precursor) }\end{array}$ & \\
\hline $\mathrm{CH} 3-\mathrm{CH} 2-\mathrm{CH} 2-\mathrm{S}(\mathrm{O})-\mathrm{CH} 2-\mathrm{CH}(\mathrm{NH} 2)-\mathrm{COOH}$ & S-Propylcysteine sulfoxide & \\
\hline $\mathrm{CH} 3-\mathrm{S}(\mathrm{O})-\mathrm{CH} 2-\mathrm{CH}(\mathrm{NH} 2)-\mathrm{COOH}$ & S-Methylcysteine sulfoxide & \\
\hline $\mathrm{CH} 2=\mathrm{CH}-\mathrm{CH} 2-\mathrm{S}(\mathrm{O})-\mathrm{S}-\mathrm{CH} 2-\mathrm{CH}=\mathrm{CH} 2$ & Allicin & \\
\hline $\begin{array}{l}\mathrm{CH} 2=\mathrm{CH}-\mathrm{CH} 2-\mathrm{S}(\mathrm{O})-\mathrm{CH} 2-\mathrm{CH}=\mathrm{CH}-\mathrm{S}-\mathrm{S}- \\
\mathrm{CH} 2-\mathrm{CH}=\mathrm{CH} 2\end{array}$ & Ajoene & \\
\hline $\mathrm{CH} 3-\mathrm{CH} 2-\mathrm{CH}=\mathrm{SO}$ & $\begin{array}{l}\text { Propanethial S-oxide } \\
\text { (lacrimatory factor) }\end{array}$ & \\
\hline $\mathrm{CH} 2=\mathrm{CH}-\mathrm{CH} 2-\mathrm{S}-\mathrm{CH} 2-\mathrm{CH}=\mathrm{CH} 2$ & Diallylsulfide & DAS \\
\hline $\mathrm{CH} 2=\mathrm{CH}-\mathrm{CH} 2-\mathrm{S}-\mathrm{S}-\mathrm{CH} 2-\mathrm{CH}=\mathrm{CH} 2$ & Diallyldisulfide & DADS \\
\hline $\mathrm{CH} 2=\mathrm{CH}-\mathrm{CH} 2-\mathrm{S}-\mathrm{S}-\mathrm{S}-\mathrm{CH} 2-\mathrm{CH}=\mathrm{CH} 2$ & Diallyltrisulfide & DATS \\
\hline $\mathrm{CH} 2=\mathrm{CH}-\mathrm{CH} 2-\mathrm{S}-\mathrm{CH} 3$ & Allylmethylsulfide & AMS \\
\hline $\mathrm{CH} 2=\mathrm{CH}-\mathrm{CH} 2-\mathrm{S}-\mathrm{S}-\mathrm{CH} 3$ & Allylmethyldisulfide & AMDS \\
\hline $\mathrm{CH} 2=\mathrm{CH}-\mathrm{CH} 2-\mathrm{S}-\mathrm{S}-\mathrm{S}-\mathrm{CH} 3$ & Allylmethyltrisulfide & AMTS \\
\hline $\mathrm{CH} 3-\mathrm{CH} 2-\mathrm{CH} 2-\mathrm{S}-\mathrm{CH} 2-\mathrm{CH} 2-\mathrm{CH} 3$ & Dipropylsulfide & DPS \\
\hline $\mathrm{CH} 3-\mathrm{CH} 2-\mathrm{CH} 2-\mathrm{S}-\mathrm{S}-\mathrm{CH} 2-\mathrm{CH} 2-\mathrm{CH} 3$ & Dipropyldisulfide & DPDS \\
\hline $\mathrm{CH} 3-\mathrm{CH} 2-\mathrm{CH} 2-\mathrm{S}-\mathrm{S}-\mathrm{S}-\mathrm{CH} 2-\mathrm{CH} 2-\mathrm{CH} 3$ & Dipropyltrisulfide & DPTS \\
\hline $\mathrm{CH} 3-\mathrm{CH} 2-\mathrm{CH} 2-\mathrm{S}-\mathrm{CH} 3$ & Propylmethylsulfide & PMS \\
\hline $\mathrm{CH} 3-\mathrm{CH} 2-\mathrm{CH} 2-\mathrm{S}-\mathrm{S}-\mathrm{CH} 3$ & Propylmethyldisulfide & PMDS \\
\hline $\mathrm{CH} 3-\mathrm{CH} 2-\mathrm{CH} 2-\mathrm{S}-\mathrm{S}-\mathrm{S}-\mathrm{CH} 3$ & Propylmethyltrisulfide & PMTS \\
\hline \multicolumn{3}{|l|}{ Water-soluble compounds } \\
\hline $\mathrm{CH} 2=\mathrm{CH}-\mathrm{CH} 2-\mathrm{S}-\mathrm{CH} 2-\mathrm{CH}(\mathrm{NH} 2)-\mathrm{COOH}$ & S-Allylcysteine & SAC \\
\hline $\mathrm{CH} 2=\mathrm{CH}-\mathrm{CH} 2-\mathrm{S}-\mathrm{S}-\mathrm{CH} 2-\mathrm{CH}(\mathrm{NH} 2)-\mathrm{COOH}$ & S-Allylmercaptocysteine & SAMC \\
\hline $\mathrm{CH} 2=\mathrm{CH}-\mathrm{CH} 2-\mathrm{S}-\mathrm{H}$ & Allylmercaptan & AM \\
\hline
\end{tabular}


(GST), a family of enzymes important in detoxi-fication of carcinogens, and cytochromes P450 (CYP), a family of enzymes that activate many chemical carcinogens in experimental animals. An increase in CYP2B1 mRNA was also observed. Treatment with the DAS metabolites diallyl sulfoxide (DASO) and diallylsulfone (DASO2) had similar effects on rat hepatic monooxygenase activities (Omar and Al-Wabel, 2010), (Brady et al., 1991), (Pan et al., 1993). DAS and its oxidation derivatives DASO and DASO2 are conjugated with glutathione, in rats. Forkert et al. (2000) tested the hypothesis that an epoxide formed from diallyl sulfone $\left(\mathrm{DASO}_{2}\right)$ is responsible for inactivation of CYP2E1 in murine and human lungs. Their results supported the premise that an epoxide formed from $\mathrm{DASO}_{2}$ mediates inactivation of lung CYP2E1. Their findings suggested that the mouse model is relevant for studies of $\mathrm{DASO}_{2}$ in human lung.

Studies in experimental animals indicate that the benefits of Allium vegetables are not limited to one species, tissue, or carcinogen. Organosulfur compounds can hinder activation of a carcinogen from its precursor, increase its metabolic detoxification, or prevent its reaction with vulnerable target cells. Additional mechanisms include a delay or a reversion of the expression of malignancy by antiproliferative activity in tumor cells and modification of signal transduction mechanisms. These speculative mechanisms in animal models should be verified in human studies to establish a causative link between some molecular properties and the cancer-preventive activity (Bianchini and Vainio, 2001).

Trace element plays an important role in chemical, biological, biochemical, metabolic, catabolic and enzymatic reactions in the living cells of plants, animals and human beings. Trace element have great significance due to their tendency to accumulate in the vital human organs over prolong period of time.

At least 25 elements are essential to human health out of which 14 are termed as trace elements. The role of trace elements in body metabolism is of prime importance. Their deficiency causes diseases, whereas their presence in excess may result in toxicity to human life (Durdana et al., 2007).

\section{Role of some microelements and minerals in human body:}

Boron (B) plays the important role in preservation of bones.

Calcium $(\mathrm{Ca})$ is necessary for a fortress of a teeth and bones. Prevents a painful exhaustion bones and development of a bony rarefication. It is necessary for normal development of a skeleton and nails, for normal work of muscles and nervous system, and for regulation of an intimate rhythm and arterial pressure (together with magnesium). Plays the important role in a metabolism of a skin, in curtailing blood.

Chromium, Chrome $(\mathrm{Cr})$ participates in regulation of a level of sugar in blood, as promotes manufacture of insulin.

Copper, Cuprum $(\mathrm{Cu})$ (alongside with zinc and manganese) antioxidant enzyme systems. It is necessary for producing melanin and a metabolism of Ferrum.

Ferrum (Iron) (Fe) is the basic microelement. Raises amount of hemoglobin in blood-red blood's bodies. It is necessary for carry of oxygen red blood bodies. It is faster acquired together with vitamin $\mathrm{C}$.

Iodine (I) provides normal work of a thyroid gland.

Magnesium $(\mathrm{Mg})$ is important for any biochemical process in an organism. Promotes balancing of minerals. It is necessary for normal job of muscles and nervous system, activity of hormones and manufacture of energy, maintenance of health of reproductive system, maintenance immune systems, restoration and updating of tissue of an organism, growth of bones, regulations of an intimate rhythm and arterial pressure (together with calcium).

Manganese $(\mathrm{Mn})$ is necessary for health of bones and nervous system.

Molybdenum (Mo) promotes a metabolism of fats and carbohydrates. It is vital for assimilation of iron and participates in manufacture of a uric acid.

Natrium and Chlorine $(\mathrm{Na}, \mathrm{Cl})$ are the basic holders of osmotic pressure, which prevents outflow of water from blood vessels in adjacent tissue.

Phosphorus $(\mathrm{P})$ is necessary for normal structure of bones, nails and a teeth and their fortress. It is important for mastering glucose and its transformation into energy.

Potassium $(\mathrm{K})$ is necessary for normal work of nervous system. Promotes maintenance of water balance in cells and tissue.

Selenium (Se) operates independently and with vitamin E as an antioxidant for neutralizations of free radicals. Promotes strengthening of immune system. Has cells, raising in them a level of enzyme-antioxidants, also protects them from destructive influence radiating and chemical carcinogens. It is capable to prevent development of a cancer in people and in animals. Deficiency of selenium in a human body results in high risk diseases by a cancer of a direct gut, dairy glands, a uterus and ovary, prostate, a bladder, easy and skin.

Vanadium (Va) is important for balance of sodium and potassium in an organism.

Zinc $(\mathrm{Zn})$ is necessary for maintenance of health of reproductive and immune systems and for restoration and updating of fabrics $\left(\mathrm{http}^{1}\right)$.

Wand and Xiang (2006) found that the tender leaves or the bulbs of garlic should be chosen preferably for the extraction of active compounds, because they are much richer in $\mathrm{Cu}, \mathrm{Fe}$, $\mathrm{Mn}, \mathrm{S}, \mathrm{Se}$ and $\mathrm{Zn}$ elements and rather low in harmful As, Cd, $\mathrm{Hg}$ and $\mathrm{Pb}$ elements as compared with other parts of garlic.

In addition, $\mathrm{K}(21,378.84 \mathrm{mg} / \mathrm{kg}), \mathrm{P}(6009.37 \mathrm{mg} / \mathrm{kg})$, $\mathrm{Mg}(1056.15 \mathrm{mg} / \mathrm{kg}), \mathrm{Na}(532.78 \mathrm{ppm})$ and $\mathrm{Ca}$ (363.61 ppm) were reported such as the major minerals in garlic bulbs (Haciseferogullari et al., 2005).

\section{Matherial and methods}

In our experiments we involved 1 vernal variety: GK Lelexír (Hungarian), and 4 winter varieties: Spring (French), Arno (French), Makói őszi (Hungarian) and Thermidrome (French). 
'Makói Őszi': Hungarian variety, which doesn't grow flowers (Allium sativum convar. sativum). It has high value of flavouring. The breeding season is middle long. We can reach even 15-20 t/ha yield.

'Sprint': French, hardnecked garlic variety with flowers (Allium sativum convar. ophidoscordon). It has fast spring, and growing. Although its productivity is excellent, its disadvantage is, that it is storable for very short time.

'Thermidrome': it belongs also to the Allium sativum convar. sativum, from France. It has a dense foliage with middle green leaves. The bulbs are big, they have a weight of 50-60 g, and a regular form. On the country of Hanságliget we have got a yield similar to the variety of 'Makói őszi'.

'Arno': French variety without flowers, which is between the spring and winter garlic varieties. To the harvest can be got round little later, than by the case of vinter varieties. Its yield is high, it can reach 10-12 t/ha. Its accomplishment is the long storability.

'GK Lelexír' (= 'Makói tavaszi'): state-recognized, Makó garlic. It was improved with clone selection from a landscape variety. It belongs to the softnecked garlics, the yield can be 10-15 t/ha.Its beneficial characteristicis, that it's excellently storable (even next year April-May), and its seasoning value is over the average (Iváncsics and Gombkötö, 2007).

These garlic varieties were grown in Hanságliget, in type of the soil was peat meadow soil. Meadow soils which can be found in Hanság are old moorland bottoms, from which ones the peaty stratas were carried away by the wind and only the clayey stratas were left. The high underground waterlevel ensures the favorable water supply of the vegetation help with this the quick and rich growth of the plants. The humus is black coloured and sticks the grains of soils to Polyhedron form together (Stefanovits, 1956). By the results of soil analysis made before, we have planed the nutrient management, and we have given a quantity of agent N:P:K = 120:100:150 kg/ha on each garlic variety.

The parcels were irrigated two times with $20 \mathrm{~mm}$ water, and we used mechanical weed clearing (hoe) three times by the breeding season.

After the harvest garlic varieties were examined in a Hungarian laboratory specializated for soil and plant analisys.

For the analisys of garlic samples a Shimadzu GC-MS + headspace (GC17A + QP $5000 \mathrm{MS}+$ Perkin-Elmer HS-40XL) mass spectrometer was used, adapted the MSZ21470-92:1998 and MSZ-21470-93:1998 Hungarian standards.

After cutting up the cloves of garlics they were mixed with methanol, and than placed in the ultrasonic bath. From the extracts 0,1-2,0 $\mathrm{ml}$ of volume were injectated in the GC-MS. The time of the thermostat was 30 minute, and the temperature was $80^{\circ} \mathrm{C}$.
The following standards was used by the analisys: Merck - metanol (suprapur - GC) and Merck - Diallyl-szulfid (>97\% of purity).

We determined the content of boron, calcium, copper, iron, potassium, magnesium, natrium, phsphorus and zinc in our garlic varieties. We searched if there were signifficant differences between the varieties, and we was looking for correlations between these elements.

The data process was made with the spreadsheet program Microsoft Excel. We set the average values of the measured results in tables, and in a column diagram. The received values was evaluated by one-way analysis of variance at a $\mathrm{P}_{1 \%}$ probability level, and multivariate correlation analysis was used (Sváb, 1973; Szücs et al., 2004).

\section{Results and discussion}

By the results of measurement it van be said, that the diallyl-sulfide of Merck was well measureable and it could be identified easily. On the used column the retention time of diallyl-sulfide was 12,49 minute. By the case of the samples of garlics there wasn't observed a peak by this retention time, however after a minute a sign was marked by 13,36 minute (dially-sulfone). By the case of all samples there was a remarkable peak by this retention time. The concentration of dially-sulfone in the samples of garlic varieties was determined by the datas of internal standard, loss on drying, and weight of matherials. The sample with highest consentration of dially- sulfone was equaled to 100 unit. The results are the following. (Fig. 1.) We also determined the content of some minerals and microelements in the examined garlic varieties. In the Table 4. the results of this measurement are shown. We have made the analysis of variance on each mineral and

Table 4 Content of some minerals and microelements in garlic varieties

\begin{tabular}{|c|c|c|c|c|c|c|}
\hline & & $\begin{array}{c}\text { Makói } \\
\text { öszi }\end{array}$ & $\begin{array}{l}\text { Thermid- } \\
\text { rome }\end{array}$ & Sprint & Arno & $\begin{array}{c}\text { GK } \\
\text { Lelexir }\end{array}$ \\
\hline Boron (B) & $\begin{array}{l}\text { mg/kg dry } \\
\text { content }\end{array}$ & 10,7 & 11,4 & 10,6 & 11,2 & 12,3 \\
\hline Calcium (Ca) & $\begin{array}{l}\mathrm{m} / \mathrm{m} \% \text { dry } \\
\text { content }\end{array}$ & 0,27 & 0,42 & 0,23 & 0,25 & 0,42 \\
\hline Copper $(\mathrm{Cu})$ & $\begin{array}{l}\text { mg/kg dry } \\
\text { content }\end{array}$ & 4,38 & 2,48 & 4,94 & 4,18 & 4,15 \\
\hline Iron $(\mathrm{Fe})$ & $\begin{array}{l}\text { mg/kg dry } \\
\text { content }\end{array}$ & 29,3 & 117 & 51,8 & 67,6 & 29 \\
\hline Potassium (K) & $\begin{array}{l}\mathrm{m} / \mathrm{m} \% \text { dry } \\
\text { content }\end{array}$ & 1,49 & 1,62 & 1,95 & 1,42 & 1,51 \\
\hline Magnesium (Mg) & $\begin{array}{l}\mathrm{m} / \mathrm{m} \% \text { dry } \\
\text { content }\end{array}$ & 0,1 & 0,11 & 0,12 & 0,09 & 0,1 \\
\hline Manganese (Mn) & $\begin{array}{l}\begin{array}{l}\text { mg/kg dry } \\
\text { content }\end{array} \\
\end{array}$ & 7,84 & 10,7 & 12 & 7,01 & 7,36 \\
\hline Natrium (Na) & $\begin{array}{l}\mathbf{m} / \mathbf{m} \% \text { dry } \\
\text { content }\end{array}$ & $<0,05$ & $<0,05$ & $<0,05$ & $<0,05$ & $<0,05$ \\
\hline Phosphorus (P) & $\begin{array}{l}\mathrm{m} / \mathrm{m} \% \text { dry } \\
\text { content }\end{array}$ & 0,42 & 0,37 & 0,48 & 0,41 & 0,53 \\
\hline Zinc (Zn) & $\begin{array}{l}\text { mg/kg dry } \\
\text { content }\end{array}$ & 17 & 15,7 & 22,2 & 17 & 26,6 \\
\hline
\end{tabular}




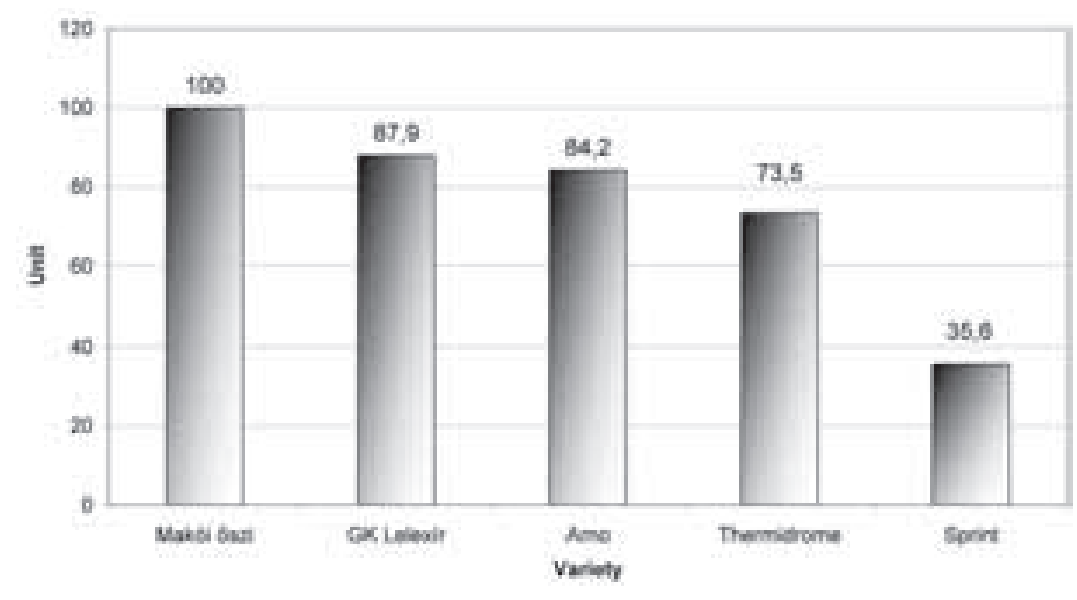

Figure 1 Dially-sulfone content int he examined garlic varieties (unit)

microelements. By all cases (except by the case of natrium) we can relate that after the accomplishment of the analysis of variance the calculated $F$ value was higher than the $F$ critical value, because of these there was a significant difference between the examined varieties at $\mathrm{P}_{1 \%}$ probability level.

Although a significant difference was shown by almost every case, we can see, that the most outstanding differences were by calcium, copper, iron and zinc. 'Thermidrome' has a very high concentration of iron, and calcium, but the content of zinc is the lowest in this variety. The highest content of zinc was measured by the 'GK Lelexír', but we can appoint, that both Hungarian varieties have very low iron concentration. 'Sprint' has high concentration of zinc, phosphorus, manganese, copper, potassium, and its content of iron has an average value.

In view of these datas we tried to find correlations between the concentrations of the minerals and microelements. There was found a strict positive correlation between boron calcium, magnesium - potassium, manganese - potassium, manganese - magnesium and zinc - phosphorus. We found a medium positive correlation between phosphorus - copper. That means, that the variation of one of these data causes the single line variation of the other data.

At the same time there was a strict negative correlation between copper - iron, and a medium negative correlation was found between copper - calcium and manganese calcium. That means, that the variation of one of these data causes the opposite line variation of the other data.

\section{References}

Bianchini F., Vainio H. (2001): Allium Vegetables and Organosulfur Compounds: Do They Help Prevent Cancer? Environmental Health Perspectives. 109 9: 893-902

Blumenthal M., Goldberg A., Brinkman J. (2000): Herbal medicine: Expanded German Commission E. Austin (TX): American Botanical Council. pp 130-33

Brady J.F., Wang M.H., Hong J.Y., Xiao F., Li Y., Yoo J.S., Ning S.M., Lee M.J., Fukuto J.M., Gapac J.M. (1991): Modulation of rat hepatic microsomal monooxygenase enzymes and cytotoxicity by diallyl sulfide. Toxicol Appl Pharmacol. 108: 342-354.
Durdana Rais Hashmi, Shahnaz Ismail, G.H. Shaikh (2007): Assessment Of The Level Of Trace Metals In Commonly Edible Vegetables Locally Avaible In The Markets Of Karachi City. Pakistan Journal of Botany, 39 (3): 747-751.

Forkert P.G., Premdas P.D., Bowers R.J. (2000): Epoxide Formation from Diallyl Sulfone Is Associated with CYP2E1 Inactivation in Murine and Human Lungs. Am. J. Respir. Cell Mol. Biol., 23 (5): 687-695.

Gombkötő Cs., Iváncsics J. (2009a): Hungarian and french garlic varieties' vegetative growing on the country of Hanság. Acta Agronomica Óváriensis. 511: 19-29.

Gombkötő Cs, Iváncsics J. (2009b): A magyarországi fokhagymatermesztés jelene és új lehetöségei. V. Növénytermesztési Tudományos Nap, Keszthely. Lektorált Konferencia Kiadvány. Akadémia Kiadó. Pp 85-89.

Haciseferogullari H., Özcan M., Demir F. and Calısir S. (2005): Some nutritional and technological properties of garlic (Allium sativum L.). Journal of Food Engineering, 68 (4): 463-469.

Iváncsics, J., Gombkötő, Cs. (2007): Néhány hagyományos és új fokhagymafajta termesztése Magyarországon. Agronapló, 11 (8): 38-39.

Koch H.P., Lawson L.D. (eds) (1996): Garlic: The Science and Therapeutic Application of Allium sativum L and related species. Baltimore, Williams and Wilkins. pp 62-4.

Lawson L.D. (1998): Garlic: A Review of Its Medicinal Effects and Indicated Active Compounds. In: Larry D. Lawson, Rudolf Bauer: Phytomedicines of Europe Chemistry and Biological Activity. American Chemical Society. pp 176-209.

Omar S. H., Al-Wabel N. A. (2010): Organosulfur compounds and possibile mechanism of garlic in cancer. Saudi Pharmaceutical Journal, 18 (1): 66-76.

Pan J., Hong J.Y., Li D., Schuetz E.G., Guzelian P.S., Huang W., Yang C.S. (1993): Regulation of cytochrome P450 2B1/2 genes by diallyl sulfone, disulfiram, and other organosulfur compounds in primary cultures of rat hepatocytes. Biochem Pharmacol. 45: 2323-2329.

Sengupta A., Ghosh S., Bhattacharjee S. (2004): Allium Vegetables in Cancer Prevention: An Overview. Asian Pacific Journal of Cancer Prevention, 5: 237-245.

Sillner L. (1990): Fokhagyma a gyógyító csoda. Medicina, Budapest. pp 22-56.

Stefanovits, P. (1956): Magyarország talajai. Akadémiai Kiadó; Budapest

Sváb, J. (1973): Biometriai módszerek a kutatásban. Mezőgazdasági Kiadó, Budapest

Szücs I. (ed.) (2004): Alkalmazott statisztika. Agroinform Kiadó és Nyomda Kft., Budapest. pp. 247-275, 312-330

Wang XP., Xiang SL. (2006): Studies on the contents of twenty elements in different parts of garlic by using ICP-OES, AAS and AFS combined with microwave decomposition method. Guang $\mathrm{Pu}$ Xue Yu Guang Pu Fen Xi. (10): 1907-1911.

1. www.ksh.hu

2. http://epp.eurostat.ec.europa.eu/portal/page? pageid $=1073,46587259 \& \_$dad $=$portal\&_schema $=$PORTAL\&p_ product_code=KS-NT-04-004

3. http://www.alvitan.com/loseflesh/minerals_en.htm 